\title{
PENGUJAN MODEL TQM EUROPEAN QUALITY AWARD (EQA) UNTUK BEBERAPA PERUSAHAAN DI INDONESIA
}

\author{
Masduki $^{*}$
}

\begin{abstract}
Rate of business competitive and customer voices changing give a stress to an organization to produce a high product quality and also a good management. Award model of quality management is a system model of quality that's used to measure reaching and testing. A fit management model of quality to be used to business environment in Indonesia. This research was done using steps, whose are deep analysis and sistematic on award totally quality management which is implemented in progressed country (Deming price, Malcolm Baldrige, and European Foundation for Quality Management), Developing of totally quality management model and measuring to connection among the empirie model of data that have got by sample in a company and also give recommendation of implementing total quality management based on developed model. The result of this research is hoped to answer a question connecting with work planning of implementing total quality management of organization in Indonesia.
\end{abstract}

Kata kunci: Manajemen kualitas total (TQM), European quality award, ISO 9000

\section{A. PENDAhULUAN}

Persaingan bisnis global saat ini menuntut perusahaan untuk lebih memperhatikan kualitas produk dan proses yang terkait dengan pemasaran, operasi maupun fungsi-fungsi lain, bahkan sampai dengan penetapan strategi keuangan. Usaha perbaikan kualitas dapat diartikan sebagai pencapaian tujuan dengan membentuk strategi yang dimulai dari tahap kontrak, desain teknis sampai dihasilkan produk, proses, jasa atau sistem yang sesuai dengan keinginan. Dalam kaitan ini, diperlukan suatu standar yang berlaku global dan memberikan prosedur yang jelas mengenai pencapaian kualitas yang diinginkan.

Standar kualitas ISO 9000 merupakan acuan yang berkaitan dengan klarifikasi dan konsistensi tentang kualitas desain, operasi dan pemeriksaan yang jelas dan diharapkan menunjang manajemen kualitas total (TQM) termasuk dalam penilaian untuk penghargaan terhadap kualitas (Lamprecth, 1996). Dalam kaitan tersebut, manajemen kualitas total (TQM) dan rekayasa ulang adalah dua metoda yang dinilai paling sukses untuk membantu perbaikan usaha yang difokuskan pada process (Hammer, 1996) dan telah menjadi acuan untuk implementasi teknologi baru (Hipkin and de Cock, 2000). Implementasi manajemen kualitas telah pula dipandang sebagai strategi usaha yang mencakup perubahan perilaku manusia, ekonomi dan biaya, bahasa usaha global, pengambilan keputusanberdasarkan fakta dan ukuran keberhasilan usaha (Figenbaum, 1999). Dalam TQM, tidak hanya pihak manajemen yang bertanggung jawab dalam memenuhi keinginan pelanggan, tetapi juga peran serta aktif seluruh komponen dalam organisasi untuk memperbaiki kualitas produk dan jasa yang dihasilkannya (Bennett and Kerr, 1996).

Untuk mengetahui posisi pencapaian penerapan manajemen kualitas, setiap organisasi atau perusahaan perlu mengevaluasi dan mengkaji dirinya (self evaluation and assessment), dan untuk itu diperlukan model

\footnotetext{
*) Dosen Fakultas Teknik Universitas Brawijaya
} 
yang dapat memberikan arahan secara sistematis untuk implementasi TQM. Untuk keperluan tersebut, dalam makalah ini diusulkan model untuk melakukan pengkajian diri dan dapat diterapkan secara universal, meskipun setiap organisasi mempunyai keunikan karakteristik. Model pengkajian diri ini secara umum mencakup semua lingkup aktivitas manajemen kualitas yang relevan. Dengan model yang dikembangkan ini diharapkan memungkinkan sebuah organisasi mengukur performansi dirinya

\section{B. LANDASAN TEORI}

\section{Manajemen Kualitas Total}

Telah banyak studi dilakukan berkaitan dengan manajemen kualitas, beberapa hal dinilai penting untuk dikaitkan, seperti kepemimpinan, manajemen sumber daya manusia, manajemen perubahan dan budaya (Ahire and O'Shaugnessy 1998, Germain and Spears 1999, dan Rungtusanatham et al. 1998). Pengembangan prinsipprinsip manajemen kualitas juga telah dilakukan, misalnya konsep perbaikan berkelanjutan (Imai,
1997), pengembangan pengetahuan (Nonaka and Takeuchi, 1995), atau pengukuran indikator kunci (Taylor, 1998).

Siklus PDCA yang diperkenalkan oleh W. Edwards Deming, yang merupakan motivasi dasar dalam TQM, banyak digunakan sebagai pendekatan untuk melaksanakan perbaikan berkelanjutan (Deming, 1993). Model dasar dan sistem kualitas yang menjadi landasan pelaksanaan manajemen kualitas total (TQM) dapat menggunakan model penjaminan kualitas ISO-9000 atau model-model penghargaan kualitas yang telah dikembangkan seperti Deming Prize (Jepang), Malcolm Baldridge Award (USA) dan European Quality Award (Eropa) (Bennett and Kerr, 1996, Rungtusanatham et al., 1998).

Berkaitan dengan ISO 9000, model pengendalian kualitas total yang melibatkan pendekatan perbaikan kualitas berkelanjutan yang dijiwai oleh siklus perbaikan PDCA seperti diperlihatkan pada Gambar 1.

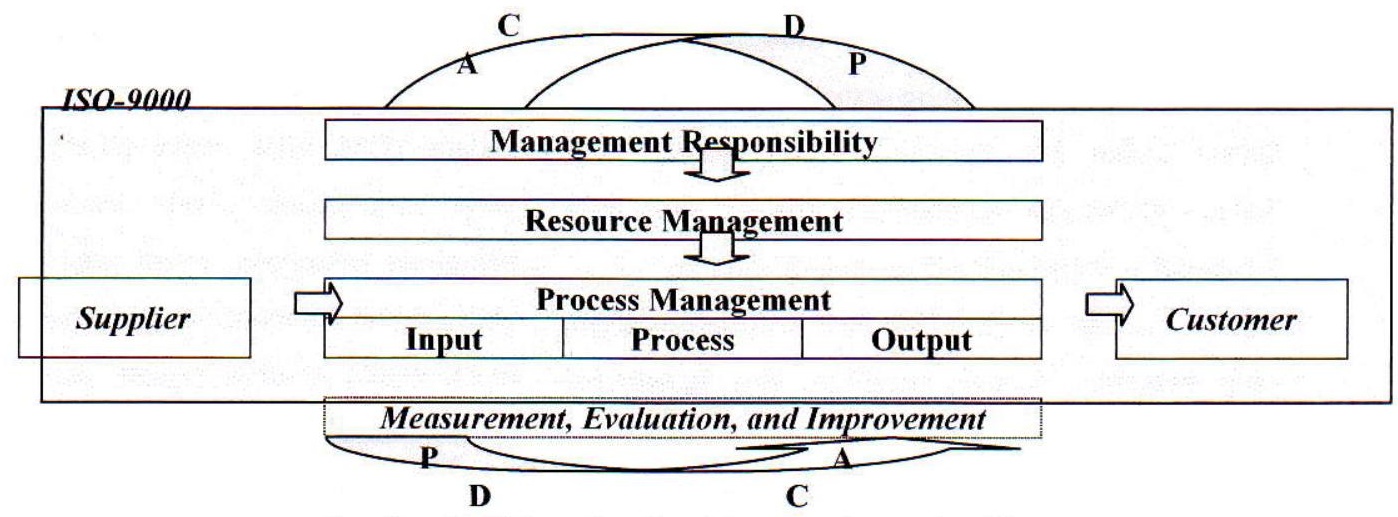

Gambar 1. Sistem dan konteks manajemen kualitas

Dalam penelitian ini, yang menjadi

fokus kajian adalah pengukuran pencapaian manajemen kualitas total dengan model European Quality Award (EQA). Dipilihnya model ini adalah karena selain model yang terakhir dikembangkan, juga karena model ini secara kontekstual dinilai mewakili lingkungan usaha di Indonesia. Indonesia 
meningkatkan kualitas produk agar dapat bersaing dengan negara-negara lainnya, oleh sebab itu pemahaman model EQA sangat diperlukan.

\section{Model European Quality Award}

Model ini dibuat dan dikembangkan oleh EFQM, serta mempunyai karakteristik yang merupakan refleksi berupa kritikan terhadap kelemahan model TQM lainnya. Kekurangan utama yang terdapat pada ide-ide awal adalah kondisi yang terlalu menyandarkan pada peran Quality Departement, Quality Director, dan pada lingkup Quality Project. Akibatnya seringkali terjadi diskoneksi dengan proses dan fungsi lain yang ada dalam organisasi. Model EQA menggarisbawahi bahwa TQM sangat erat kaitannya dengan manajemen strategis yang melibatkan pihak manajemen senior. Model EQA menegaskan bahwa TQM memerlukan pendekatan manajemen secara integral melalui pengkombinasian subjek dasar manajemen seperti kepemimpinan, kebijakan dan strategi, sumberdaya serta proses.

Pada Gambar 2, antar sasaran terkait diasumsikan memiliki hubungan. Pengaruh masingmasing bagian memiliki bobot yang berbeda, yang besarnya bervariasi tergantung pada karakteristik organisasi perusahaannya. Sasaran yang ingin dicapai dengan model tersebut adalah performansi organisasi yang sempurna dan konsisten, yang pada akhirnya akan memberikan perbaikan pada organisasi tersebut.

Model ini menunjukkan hubungan antara lingkup fokus dari pendekatan (enabler) dan performansi (result) yang berupa hubungan sebab akibat. Kelima lingkup pendekatan berfokus pada proses, sedangkan lingkup performansi berkaitan dengan output hasil usaha. Dalam hal ini, semua komponen model dipandang penting dalam evaluasi diri menuju kualitas total. Organisasi bebas menentukan sasaran kualitas dan mengalokasikan sumber daya yang diperlukan untuk mencapai sasaran. Realisasi pencapaian sasaran ditentukan oleh penilaian stake-holder, dengan demikian sangat penting agar faktafakta tentang performansi organisasi diterima dan diputuskan oleh kelompok tersebut. Keterlibatan para stake-holder akan meningkatkan manfaat kajian diri. Tujuan utama model penilaian ini adalah berbasis fakta, sehingga pengumpulan informasi dan proses komunikasi lebih penting artinya dibandingkan dengan hasil penilaian.

\section{METODE}

Penelitian ini diawali oleh kajian literatur yang relevan dengan menggunakan analisis eksploratori untuk mendefinisikan faktor yang akan menjadi variabel pembentuk model, keterkaitan antar variabel model (causal relationship) berdasarkan hubungan logis dan teoritis, serta memperhatikan efektivitas model untuk mengukur implementasi manajemen kualitas total. Dari model (variabel laten) berdasarkan Gambar 2, disusun sub-variabel (variabel manifes)

Analisis yang dilakukan adalah

- normalisasi data

- uji reliabilitas

- Uji Konstruk Analisis korelasi kanonik

- Analisis regresi

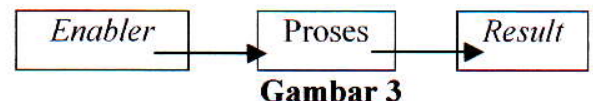

Model EQA yang disederhanakan. 


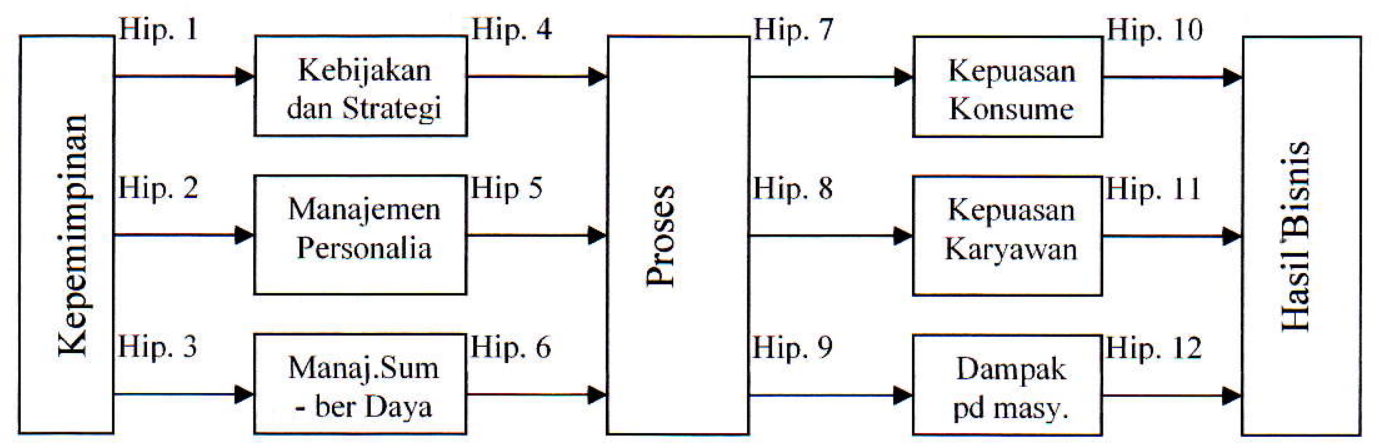

Gambar 4. Hipotesis untuk menguji model EQA

\section{ANALISA}

\section{Uji Reliabilitas}

Tabel 1. Koefisien Reliabitas

\begin{tabular}{|l|c|c|c|}
\hline \multicolumn{1}{|c|}{$\begin{array}{c}\text { Kelompok } \\
\text { Variabel }\end{array}$} & $\mathbf{k}$ & \multicolumn{2}{c|}{ Koefisien Alfa cronbach } \\
\cline { 3 - 4 } & Manufaktur & Pelayanan \\
\hline Kepemimpinan & 7 & 0.890 & 0.945 \\
\hline $\begin{array}{l}\text { Kebijakan dan } \\
\text { Strategi }\end{array}$ & 9 & 0.899 & 0.956 \\
\hline $\begin{array}{l}\text { Manajemen } \\
\text { Personalia }\end{array}$ & 7 & 0.892 & 0.955 \\
\hline $\begin{array}{l}\text { Manajemen Sumber } \\
\text { daya }\end{array}$ & 11 & 0.917 & 0.964 \\
\hline Manajemen Proses & 10 & 0.927 & 0.975 \\
\hline Penilaian Konsumen & 13 & 0.916 & 0.952 \\
\hline Penilaian Karyawan & 12 & 0.943 & 0.967 \\
\hline $\begin{array}{l}\text { Penilaian } \\
\text { Masyarakat }\end{array}$ & 8 & 0.941 & 0.906 \\
\hline Hasil Bisnis & 16 & 0.961 & 0.970 \\
\hline
\end{tabular}

Keterangan : $k$ adalah jumlah item pertanyaan per kelompok pertanyaan

$\alpha$ adalah nilai koefisien alpha cronbach.

\section{Uji Konstruk}

Hasil lengkap dari uji konstruk tidak dicantumkan dalam makalah ini karena harus menjelaskan per item pertanyaan sebanyak 93 . Secara umum, item pertanyaan mempunyai koefisien korelasi dengan nilai total yang lebih besar dari $\mathrm{R}$ kritis $(0.349)$ sehingga dinilai valid, kecuali item Q201 (pertanyaan kebijakan dan strategi no.1), Q305 (pertanyaan manajemen personalia no. 5) dan Q710 (pertanyaan penilaian Keempat proposisi di atas akan dinyatakan dalam 12 hipotesis yang dapat diuji secara statistik sebagai berikut karyawan no. 10), sehingga pertanyaan-pertanyaan tersebut dikeluarkan dalam proses analisis selanjutnya.

\section{Analisis Korelasi Kanonik Antar Variabel}

Dari hasil perhitungan pada Tabel 2, terlihat bahwa nilai koefisien korelasi kanonik pada hubungan antar variabel dalam model EQA berada diatas 0.800 . Ini berarti bahwa terdapat hubungan yang signifikan antar variabel laten yang diuji, sehingga semua hipotesis yang diajukan dapat diterima.

Dari hasil ini pula dapat disimpulkan bahwa untuk gabungan perusahaan manufaktur dan jasa, hipotesis 9 (hubungan antara variabel proses dengan variabel dampak pada masyarakat) serta hipotesis 12 (hubungan antara variabel dampak pada masyarakat dengan variabel hasil bisnis) relatif lebih lemah dari hipotesa lainnya walaupun koefisiennya juga signifikan. Hal lainnya adalah bahwa terdapat kesamaan antara perusahaan bidang manufaktur dan bidang jasa yaitu mempunyai persepsi yang sama tentang pentingnya kepuasan karyawan terhadap hasil bisnis, dimana didalamnya menyangkut penghargaan terhadap karyawan atas hasil pekerjaannya. 
Tabel 2

Hasil perhitungan korelasi kanonik pada model EQA

\begin{tabular}{|c|c|c|c|c|}
\hline \multirow[t]{2}{*}{ No. } & \multirow[t]{2}{*}{ Hipotesis } & \multicolumn{3}{|c|}{$\begin{array}{c}\text { Koefisien korelasi kanonik } \\
\text { perusahaan }\end{array}$} \\
\hline & & Manufaktur & Pelayanan & Gabungan \\
\hline 1. & $\begin{array}{c}\text { Hipotesis } \\
1 \\
\end{array}$ & 0.945 & 0.970 & 0.964 \\
\hline 2. & $\begin{array}{l}\text { Hipotesis } \\
2\end{array}$ & 0.958 & 0.968 & 0.957 \\
\hline 3. & $\begin{array}{l}\text { Hipotesis } \\
3\end{array}$ & 0.995 & 0.964 & 0.942 \\
\hline 4. & $\begin{array}{c}\text { Hipotesis } \\
4\end{array}$ & 0.995 & 0.951 & 0.955 \\
\hline 5. & $\begin{array}{l}\text { Hipotesis } \\
5\end{array}$ & 0.989 & 0.969 & 0.962 \\
\hline 6. & $\begin{array}{l}\text { Hipotesis } \\
6\end{array}$ & 0.963 & 0.969 & 0.963 \\
\hline 7. & $\begin{array}{c}\text { Hipotesis } \\
7\end{array}$ & 0.995 & 0.954 & 0.951 \\
\hline 8. & $\begin{array}{c}\text { Hipotesis } \\
8 \\
\end{array}$ & 0.994 & 0.956 & 0.955 \\
\hline 9. & $\begin{array}{l}\text { Hipotesis } \\
9\end{array}$ & 0.985 & 0.925 & 0.864 \\
\hline 10. & $\begin{array}{c}\text { Hipotesis } \\
10\end{array}$ & 0.998 & 0.972 & 0.961 \\
\hline 11. & $\begin{array}{c}\text { Hipotesis } \\
11\end{array}$ & 0.999 & 0.976 & 0.970 \\
\hline 12. & $\begin{array}{l}\text { Hipotesis } \\
12\end{array}$ & 0.999 & 0.961 & 0.896 \\
\hline 13. & $\begin{array}{l}\text { Hipotesis } \\
13\end{array}$ & - & - & 0.987 \\
\hline & $\begin{array}{c}\text { Hipotesis } \\
14\end{array}$ & - & - & 0.981 \\
\hline
\end{tabular}

Dengan tingginya koefisien korelasi kanonik yang telah dicapai dalam penelitian ini menunjukkan bahwa gabungan data dari keempat organisasi yang dijadikan sampel penelitian di atas telah memiliki pola dan aktivitas manajemen kualitas total yang sesuai dengan model yang dikembangkan.

\section{Analisis Regresi}

Pada analisis regresi seperti tercantum dalam Tabel 3, $\beta$ merupakan koefisien regresi yang telah distandardisasi yang ekivalen dengan koefisien path analysis. Selanjutnya signifikansi statistik koefisien path analysis dapat diuji dengan uji-t dan hipotesis 1 hingga 14 dievałtrasi. dengan interpretasi atau koefisien determinasi $\mathrm{R}^{2}$. Sesuai hasil analisis regresi, seperti halnya analisis koefisien korelasi kanonik, bahwa hipotesis 9 dan hipotesis 12 mempunyai nilai $\beta$ yang lebih rendah dari pada hipotesis lainnya. Hal ini ditunjukkan dengan nilai $\beta$ sebesar :

- Manufaktur : $\beta=0.549$ (hipotesis 9) dan $\beta=0.622$ (hipotesis 12)

- Pelayanan : $\beta=0.805$ (hipotesis 9) dan $\beta=0.825$ (hipotesis 12)

- Gabungan: $\beta=0.758$ (hipotesis 9) dan $\beta=0.787$ (hipotesis 12 )

Nilai $R^{2}$ (koefisien determinasi multiple) pada tabel di atas menunjukkan besarnya variasi data respon (dependen variabel) yang disebabkan oleh model regresi yang dibandingkan terhadap random error.

\section{Perbandingan dan Diskusi}

Selain model EQA, beberapa negara maju melakukan penilaian terhadap pencapaian tingkat kualitas melalui pemberian penghargaan kepada perorangan atau perusahaan yang dinilai mampu membuat terobosan dalam bidang perbaikan kualitas. Ada tiga macam penghargaan perbaikan kualitas yang mengacu pada kerangka kerja TQM secara umum yang diakui memiliki reputasi sebagai acuan dalam penilaian usaha perbaikan kualitas, yaitu :

- Deming Prize (DP) di Jepang dan terbuka untuk perusahaan dari luar Jepang

- The Malcolm Balbridge National Quality Award (MB) di Amerika Serikat dan Canada

- European Quatity Award (EQA) untuk negara-negara eropa 
Penilaian ketiga penghargaan tersebut secara umum didasarkan pada kualitas dan pelayanan sebagai model penerapan TQM dengan menganalisis perubahaan organisasi secara berkesinambungan, meningkatkan motivasi untuk perbaikan yang berkelanjutan, serta memusatkan perhatian kepada strategi pelaksanaan kegiatan perbaikan tersebut.

\section{Tabel 3}

Hasil Perhitungan Analisis Regresi

\begin{tabular}{|c|c|c|c|c|}
\hline \multirow{2}{*}{$\begin{array}{c}\text { Hipo- } \\
\text { tesis }\end{array}$} & \multicolumn{4}{|c|}{ Organisasi Manufaktur } \\
\cline { 2 - 5 } & $\mathbf{R}^{2}$ & $\boldsymbol{\beta}$ & $\begin{array}{c}\text { Std. } \\
\text { Error }\end{array}$ & $\begin{array}{c}\text { Koef. } \\
\text { Error }\end{array}$ \\
\hline 1 & 0.695 & 0.834 & 0.393 & 0.285 \\
\hline 2 & 0.566 & 0.753 & 0.497 & 0.360 \\
\hline 3 & 0.460 & 0.678 & 0.481 & 0.349 \\
\hline 4 & 0.709 & 0.842 & 0.334 & 0.243 \\
\hline 5 & 0.709 & 0.842 & 0.334 & 0.222 \\
\hline 6 & 0.849 & 0.921 & 0.384 & 0.182 \\
\hline 7 & 0.747 & 0.864 & 0.306 & 0.234 \\
\hline 8 & 0.793 & 0.891 & 0.332 & 0.254 \\
\hline 9 & 0.302 & 0.549 & 0.701 & 0.537 \\
\hline 10 & 0.877 & 0.937 & 0.250 & 0.196 \\
\hline 11 & 0.841 & 0.917 & 0.285 & 0.205 \\
\hline 12 & 0.387 & 0.622 & 0.559 & 0.396 \\
\hline 13 & 0.763 & 0.873 & 0.302 & 0.235 \\
\hline 14 & 0.758 & 0.871 & 0.324 & 0.248 \\
\hline
\end{tabular}

\begin{tabular}{|l|l|l|l|l|l|l|l|l|l|}
\hline No & Hipotesis & $\mathbf{R}^{\mathbf{2}}$ & $\boldsymbol{\beta}$ & $\begin{array}{c}\text { Standard } \\
\text { Error }\end{array}$ & $\begin{array}{c}\text { Koef } \\
\text { Error }\end{array}$ & $\mathbf{R}^{\mathbf{2}}$ & $\boldsymbol{\beta}$ & $\begin{array}{c}\text { Standard } \\
\text { Error }\end{array}$ & $\begin{array}{c}\text { Koef. } \\
\text { Error }\end{array}$ \\
\hline & & 0.911 & 0.954 & 0.311 & 0.149 & 0.899 & 0.948 & 0.338 & 0.115 \\
\hline 1. & Hipotesis 1 & 0.852 & 0.923 & 0.422 & 0.202 & 0.855 & 0.924 & 0.441 & 0.150 \\
\hline 2. & Hipotesis 2 & 0.866 & 0.931 & 0.367 & 0.176 & 0.846 & 0.920 & 0.405 & 0.137 \\
\hline 3. & Hipotesis 3 & 0.859 & 0.927 & 0.371 & 0.172 & 0.861 & 0.930 & 0.393 & 0.136 \\
\hline 4. & Hipotesis 4 & 0.862 & 0.928 & 0.368 & 0.168 & 0.878 & 0.937 & 0.373 & 0.122 \\
\hline 5. & Hipotesis 5 & 0.849 & 0.921 & 0.384 & 0.182 & 0.861 & 0.927 & 0.399 & 0.139 \\
\hline 6. & Hipotesis 6 & 0.755 & 0.869 & 0.408 & 0.202 & 0.820 & 0.906 & 0.379 & 0.131 \\
\hline 7. & Hipotesis 7 & 0.752 & 0.867 & 0.518 & 0.257 & 0.802 & 0.895 & 0.473 & 0.163 \\
\hline 8. & Hipotesis 8 & 0.648 & 0.805 & 0.458 & 0.227 & 0.575 & 0.758 & 0.540 & 0.186 \\
\hline 9. & Hipotesis 9 & 0.732 & 0.855 & 0.501 & 0.273 & 0.823 & 0.907 & 0.446 & 0.171 \\
\hline 10. & Hipotesis 10 & 0.803 & 0.896 & 0.429 & 0.200 & 0.844 & 0.919 & 0.419 & 0.146 \\
\hline 11. & Hipotesis 11 & 0.680 & 0.825 & 0.547 & 0.324 & 0.619 & 0.787 & 0.654 & 0.285 \\
\hline 12. & Hipotesis 12 & 0.895 & 0.946 & 0.321 & 0.154 & 0.906 & 0.952 & 0.327 & 0.115 \\
\hline 13. & Hipotesis 13 & 0.784 & 0.886 & 0.404 & 0.201 & 0.834 & 0.913 & 0.381 & 0.131 \\
\hline 14. & Hipotesis 14 & & & & & & & & \\
\hline
\end{tabular}

Keterangan : Semua analisis menggunakan tingkat signifikansi $\alpha=0.05$.

\section{Penghargaan Deming Prize (DP)} pertama kali diberikan pada tahun 1951 oleh The Japanese Union of Scientists and Engineers (JUSE, Nikkagiren) untuk menghormati jasa Dr. W. Edward Deming dalam usahanya meningkatkan kualitas produk dan proses serta perbaikan yang berkelanjutan dalam bidang pengendalian kualitas di Jepang. Ada lima bentuk penghargaan yang diberikan, yaitu kriteria perorangan, aplikasi, aplikasi untuk industri kecil, divisi dan pengendalian kualitas perusahaan. Penilain ditujukan pada penerapan pengendalian kualitas terpadu dengan melihat pelaksanaan kebijakan penerapan kualitas beserta aktivitasnya, pelaksanaan kualitas terpadu secara menyeluruh pada perusahaan (Company Wide Quality Control), serta pengendalian hasil (peningkatan kualitas, peningkatan produktifitas, penurunan biaya, perluasan pasar, peningkatan keuntungan dan lain sebagainya) yang ingin dicapai dengan menerapkan teknik-teknik statistika dan serta pembentukan kelompok-kelompok kecil untuk perbaikan mutu yang dikenal sebagai quality circles. Unjuk kerja pelaksanaan CWQC 
kemudian diberi nilai khusus sesuai standar yang telah ditetapkan.

Penghargaan Malcolm Baldrige mulai diberikan pada tahun 1987 yang merupakan penghargaan berskala nasional di Amerika Serikat, dan dalam perkembangannya juga diberikan kepada perusahaan di Kanada yang juga menjadi cakupan asosiasi kualitas di amerika utara $(A S Q C)$. Tujuan pemberian penghargaan ini adalah :

a. Meningkatkan kesadaran akan pentingnya kualitas beserta pemahamannya dalam upaya mencapai kualitas yang baik,

b. Memberikan pengakuan terhadap perusahaan yang telah melaksanakan prosedur kualitas dengan baik, serta

c. Mempublikasikan kebijakan dan strategi yang melandasi kesuksesan pelaksanaan kualitas.

Ada tiga kategori penghargaan yang diberikan, yaitu kualitas di bidang manufaktur, pelayanan atau sejenisnya dan usaha kecil. Pemberian penghargaan didasarkan pada suatu standar penilaian yang telah ditulis dalam suatu formulir yang harus diisi dan diketahui oleh peserta dan berisi informasi serta data mengenai proses pelaksanaan kualitas pada perusahaan beserta hasil-hasil peningkatan yang telah dicapai.

Secara lengkap kriteria yang digunakan oleh ketiga penghargaan kualitas tersebut diberikan pada Tabel 4 (Bohoris, 1995).
Tabel 4

\section{Kriteria penilaian pada DP, MB dan EQA}

\begin{tabular}{lll}
\hline Deming Prize & \multicolumn{1}{c}{$\begin{array}{c}\text { Malcolm } \\
\text { Baldrige }\end{array}$} & $\begin{array}{c}\text { Eur. } \\
\text { Quality } \\
\text { Awards }\end{array}$ \\
\hline Policies & Leadership & Leadership \\
\hline $\begin{array}{l}\text { Organization \& its } \\
\text { operation }\end{array}$ & $\begin{array}{l}\text { Information } \\
\text { analysis }\end{array}$ & $\begin{array}{l}\text { Policy \& } \\
\text { strategy }\end{array}$ \\
\hline $\begin{array}{l}\text { Education \& } \\
\text { dissemination }\end{array}$ & $\begin{array}{l}\text { Strategic } \\
\text { planning }\end{array}$ & $\begin{array}{l}\text { People } \\
\text { management }\end{array}$ \\
\hline $\begin{array}{l}\text { Information } \\
\text { gathering, } \\
\text { communications \& } \\
\text { utilization }\end{array}$ & $\begin{array}{l}\text { Human resource } \\
\text { development \& } \\
\text { management }\end{array}$ & Resources \\
\hline Analysis & Process & Processes \\
\hline Standardization & Business Results & $\begin{array}{l}\text { Customer } \\
\text { Satisfaction }\end{array}$ \\
\hline Control/management & Customer focus & $\begin{array}{l}\text { People } \\
\text { satisfaction }\end{array}$ \\
\hline Quality assurance & \& satisfaction & Impact on \\
& & society \\
\hline Effects & & Business \\
& & Results \\
\hline Future Plans & & \\
\hline & & \\
\hline
\end{tabular}

Dengan memperhatikan kriteria masing-masing penghargaan, dapat disusun kriteria dasar untuk tujuan studi perbandingan yang dinilai mewakili penilaian ketiga pengahargaan tersebut seperti yang diberikan pada Tabel 5.

\section{Tabel 5. teria dasar untuk perbandingan} penghargaan kualitas

\begin{tabular}{|c|c|c|}
\hline Kriteria & & Kategori \\
\hline $\begin{array}{l}\text { Kepemim- } \\
\text { pinan }\end{array}$ & $\stackrel{*}{*}$ & $\begin{array}{l}\text { Keterlibatan pemimpin dalam } \\
\text { TQM } \\
\text { Peran dan komitmen pemimpin } \\
\text { Dampak terhadap masyarakat* }\end{array}$ \\
\hline $\begin{array}{l}\text { Strategi dan } \\
\text { kebijakan }\end{array}$ & $\nLeftarrow$ & $\begin{array}{l}\text { Pembentukan dan penyusunan } \\
\text { strategi dan kebijakan } \\
\text { Komunikasi strategi dan } \\
\text { kebijakan } \\
\text { Perbaikan strategi dan kebijakan }\end{array}$ \\
\hline $\begin{array}{l}\text { Manajemen } \\
\text { sumber daya }\end{array}$ & $*$ & \begin{tabular}{lll}
\multicolumn{3}{l}{ Manajemen, pemanfaatan dan } \\
\multicolumn{2}{l}{ analisis informasi } \\
Manajemen & sumber & daya \\
material & & \\
$\begin{array}{l}\text { Manajemen } \\
\text { teknologi }\end{array}$ & sumber & daya \\
$\begin{array}{l}\text { Manajemen } \\
\text { keuangan }\end{array}$ & sumber & daya \\
& &
\end{tabular} \\
\hline $\begin{array}{l}\text { Manajemen } \\
\text { sumber daya } \\
\text { manusia }\end{array}$ & $\nLeftarrow$ & $\begin{array}{l}\text { Manajemen dan perencanaan } \\
\text { SDM } \\
\text { Keterlibatan pekerja }\end{array}$ \\
\hline
\end{tabular}




\begin{tabular}{|c|c|c|}
\hline & $\%$ & $\begin{array}{l}\text { Pendidikan dan pelatihan } \\
\text { Unjuk kerja dan penghargaan } \\
\text { untuk pekerja } \\
\text { Kepuasan pekerja }\end{array}$ \\
\hline $\begin{array}{l}\text { Kualitas } \\
\text { proses }\end{array}$ & $\%$ & $\begin{array}{l}\text { Manajemen kualitas proses } \\
\text { Penerapan dan perbaikan kualitas } \\
\text { proses }\end{array}$ \\
\hline Hasil & $\%$ & $\begin{array}{l}\text { Kualitas dan hasil operasi } \\
\text { Hasil usaha (business results) }\end{array}$ \\
\hline $\begin{array}{l}\text { Manajemen } \\
\text { dan } \\
\text { kepuasan } \\
\text { konsumen }\end{array}$ & $\%$ & $\begin{array}{l}\text { Manajemen konsumen* } \\
\text { Kepuasan konsumen* }\end{array}$ \\
\hline
\end{tabular}

\section{Tujuan eksternal}

Jika diambil pola yang dikembangkan dalam menyusun kriteria penilaian, secara umum ada dua hal yang ingin dicapai [DuPont, 1997] yaitu :

- Eksternal, berkaitan dengan pasar dan konsumen, dan

- Internal, berkaitan dengan strategi dan rencana operasi,

dimana keduanya memerlukan landasan analisis dan dukungan informasi yang memadai.

Untuk masing-masing kriteria, terdapat kesamaan maupun perbedaan di antara ke tiga penghargaan. Hal ini dapat dijelaskan sebagai berikut :

- Kriteria kepemimpinan digunakan oleh ketiga penghargaan dalam penilaian. Dari uraian rinci, lebih jauh terlihat bahwa DP dan EQA menekankan keterlibatan langsung elemen organisasi dalam TQM, sedangkan MB lebih terfokus pada konsumen.

- Pada kriteria manajemen sumber daya, MB sangat intensif dalam pemanfaatan dan analisis informasi yang berkaitan dengan kualitas, konsumen, operasional dan finansial, serta bagaimana informasi tersebut digunakan untuk mendukung keputusan dan perencanaan. Pada kriteria ini, penilaian atas material, teknologi dan keuangan adalah penialaian baru yang digunakan oleh EQA (tidak digunakan pada DP dan MB). Pada penilaian tersebut EQA memperhatikan betul bagaimana perusahaan dapat menerapkan dan mengadopsi kualitas yang memberi dampak pada faktor finansial dan non finansial (material dan teknologi). Hal ini disadari sebagai hal baru yang berperan besar dalam persaingan di pasar global seiring dengan terbentuknya pasar bersama di Eropa.

- Tidak terdapat perbedaan yang nyata pada kriteria strategi dan kebijakan diantara penilaian oleh ketiga penghargaan. Walaupun demikian, pada penilaian komunikasi strategi dan kebijakan, MB terlihat lebih fokus pada bisnis dan lebih realistis dalam pelaksanaan program. Seperti halnya pada kriteria kepemimpinan, $\quad$ MB kembali memperlihatkan perhatian yang besar pada sisi konsumen.

- Ketiga penghargaan memberikan perhatian yang seimbang pada penilaian manajemen dan perencanaan sumber daya manusia, serta pendidikan dan latihan. Dalam hal keterlibatan, unjuk kerja dan penghargaan, serta kepuasan pekerja, DP tidak memberikan penilaian secara khusus. Hal ini dilandasi oleh kebijakan yang umumnya dianut di Jepang, yaitu long-life employement. Dalam penilaian-penilaian tersebut, MB dan EQA memberikan penilaiannya, bahkan EQA memberikan kriteria-kriteria baru dan lebih luas dikaitkan dengan peran kunci manusia. 
kemudian diberi nilai khusus sesuai standar yang telah ditetapkan.

Penghargaan Malcolm Baldrige mulai diberikan pada tahun 1987 yang merupakan penghargaan berskala nasional di Amerika Serikat, dan dalam perkembangannya juga diberikan kepada perusahaan di Kanada yang juga menjadi cakupan asosiasi kualitas di amerika utara $(A S Q C)$. Tujuan pemberian penghargaan ini adalah :

a. Meningkatkan kesadaran akan pentingnya kualitas beserta pemahamannya dalam upaya mencapai kualitas yang baik,

b. Memberikan pengakuan terhadap perusahaan yang telah melaksanakan prosedur kualitas dengan baik, serta

c. Mempublikasikan kebijakan dan strategi yang melandasi kesuksesan pelaksanaan kualitas.

Ada tiga kategori penghargaan yang diberikan, yaitu kualitas di bidang manufaktur, pelayanan atau sejenisnya dan usaha kecil. Pemberian penghargaan didasarkan pada suatu standar penilaian yang telah ditulis dalam suatu formulir yang harus diisi dan diketahui oleh peserta dan berisi informasi serta data mengenai proses pelaksanaan kualitas pada perusahaan beserta hasil-hasil peningkatan yang telah dicapai.

Secara lengkap kriteria yang digunakan oleh ketiga penghargaan kualitas tersebut diberikan pada Tabel 4 (Bohoris, 1995).
Tabel 4

Kriteria penilaian pada DP, MB dan EQA

\begin{tabular}{lll}
\hline \multicolumn{1}{c}{ Deming Prize } & \multicolumn{1}{c}{$\begin{array}{c}\text { Malcolm } \\
\text { Baldrige }\end{array}$} & $\begin{array}{c}\text { Eur. } \\
\text { Quality } \\
\text { Awards }\end{array}$ \\
\hline Policies & Leadership & Leadership \\
\hline $\begin{array}{l}\text { Organization \& its } \\
\text { operation }\end{array}$ & $\begin{array}{l}\text { Information } \\
\text { analysis }\end{array}$ & $\begin{array}{l}\text { Policy \& } \\
\text { strategy }\end{array}$ \\
\hline $\begin{array}{l}\text { Education \& } \\
\text { dissemination }\end{array}$ & $\begin{array}{l}\text { Strategic } \\
\text { planning }\end{array}$ & $\begin{array}{l}\text { People } \\
\text { management }\end{array}$ \\
\hline $\begin{array}{l}\text { Information } \\
\text { gathering, } \\
\text { communications \& } \\
\text { utilization }\end{array}$ & $\begin{array}{l}\text { Human resource } \\
\text { development \& } \\
\text { management }\end{array}$ & Resources \\
\hline Analysis & Process & \\
\hline Standardization & Business Results & $\begin{array}{l}\text { Customer } \\
\text { Satisfaction }\end{array}$ \\
\hline Control/management & Customer focus & $\begin{array}{l}\text { People } \\
\text { satisfaction }\end{array}$ \\
\hline Quality assurance & Processes \\
\hline Effects & & $\begin{array}{l}\text { Impact on } \\
\text { society }\end{array}$ \\
\hline Future Plans & & $\begin{array}{l}\text { Business } \\
\text { Results }\end{array}$ \\
\hline
\end{tabular}

Dengan memperhatikan kriteria masing-masing penghargaan, dapat disusun kriteria dasar untuk tujuan studi perbandingan yang dinilai mewakili penilaian ketiga pengahargaan tersebut seperti yang diberikan pada Tabel 5 .

Tabel 5. teria dasar untuk perbandingan penghargaan kualitas

\begin{tabular}{|c|c|c|}
\hline Kriteria & & Kategori \\
\hline $\begin{array}{l}\text { Kepemim- } \\
\text { pinan }\end{array}$ & $*$ & $\begin{array}{l}\text { Keterlibatan pemimpin dalam } \\
\text { TQM } \\
\text { Peran dan komitmen pemimpin } \\
\text { Dampak terhadap masyarakat* }\end{array}$ \\
\hline $\begin{array}{l}\text { Strategi dan } \\
\text { kebijakan }\end{array}$ & 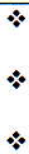 & 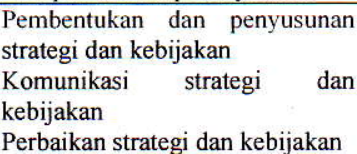 \\
\hline $\begin{array}{l}\text { Manajemen } \\
\text { sumber daya }\end{array}$ & 8 & \begin{tabular}{lll}
\multicolumn{3}{l}{ Manajemen, pemanfaatan dan } \\
analisis informasi & \\
$\begin{array}{l}\text { Manajemen } \\
\text { material }\end{array}$ & sumber & daya \\
$\begin{array}{l}\text { Manajemen } \\
\text { teknologi }\end{array}$ & sumber & daya \\
$\begin{array}{l}\text { Manajemen } \\
\text { keuangan }\end{array}$ & sumber & daya \\
& &
\end{tabular} \\
\hline $\begin{array}{l}\text { Manajemen } \\
\text { sumber daya } \\
\text { manusia }\end{array}$ & $*$ & $\begin{array}{l}\text { Manajemen dan perencanaan } \\
\text { SDM } \\
\text { Keterlibatan pekerja }\end{array}$ \\
\hline
\end{tabular}




\begin{tabular}{|c|c|c|}
\hline & $\%$ & $\begin{array}{l}\text { Pendidikan dan pelatihan } \\
\text { Unjuk kerja dan penghargaan } \\
\text { untuk pekerja } \\
\text { Kepuasan pekerja }\end{array}$ \\
\hline $\begin{array}{l}\text { Kualitas } \\
\text { proses }\end{array}$ & $\%$ & $\begin{array}{l}\text { Manajemen kualitas proses } \\
\text { Penerapan dan perbaikan kualitas } \\
\text { proses }\end{array}$ \\
\hline Hasil & $\%$ & $\begin{array}{l}\text { Kualitas dan hasil operasi } \\
\text { Hasil usaha (business results) }\end{array}$ \\
\hline $\begin{array}{l}\text { Manajemen } \\
\text { dan } \\
\text { kepuasan } \\
\text { konsumen }\end{array}$ & & $\begin{array}{l}\text { Manajemen konsumen* } \\
\text { Kepuasan konsumen* }\end{array}$ \\
\hline
\end{tabular}

\section{E. KESIMPULAN}

Pada perbandingan yang mencakup 7 kriteria (kepemimpinan, strategi dan kebijakan, manajemen sumber daya, manajemen sumber daya manusia, kualitas proses, hasil, dan manajemen dan kepuasan konsumen) dapat ditarik kesimpulan bahwa DP berfokus pada kondisi kualitas pada tingkat mikro, MB terasa kuat dilandasi oleh pemenuhan konsumen (customer driven), sedangkan EQA mencoba menilai secara lengkap dan luas semua aspek yang berkaitan dengan kualitas.

\section{DAFTAR PUSTAKA}

Ahire S.L., and O'Shaughnessy, K.C., 1998, The Role of Top Management Commitment in Quality Management: an Empirical Analysis of the Auto Parts Industry, International Journal of Quality Science, 3(1), pp.5-37.

Bennet, L.M., and Kerr, M.A., 1996, A System Approach to the Implementation of Total Quality Management, Total Quality Management, 7(4), pp.631-665.

Bohoris, G.A., 1995, A Comparative Assessment of Some Major Quality Awards, Int. J. Quality \& Reliability Management, 12(9), pp.30-43
Deming, W.E. 1993, The New Economics for Industry Government Education, the MIT-CAES, Cambridge.

DuPont, L.R., 1997, The Criteria: A Looking Glass to Americans' Understanding of Quality, Quality Progress, 30(9), pp.8995.

Figenbaum, A.V., 1999, The New Quality for the Twenty-first Century, The TQM Magazine, 11(6), pp.376-383. 